Preliminary Classification of Water Areas Within the Atchafalaya Basin Floodway System by Using Landsat Imagery

Open-File Report 2008-1320 



\section{Preliminary Classification of Water Areas Within the Atchafalaya Basin Floodway System by Using Landsat Imagery}

By Yvonne C. Allen, Glenn C. Constant, and Brady R. Couvillion

Open-File Report 2008-1320 


\section{U.S. Department of the Interior DIRK KEMPTHORNE, Secretary}

\section{U.S. Geological Survey \\ Mark D. Myers, Director}

\section{U.S. Geological Survey, Reston, Virginia: 2008}

For product and ordering information:

World Wide Web: http://www.usgs.gov/pubprod

Telephone: 1-888-ASK-USGS

For more information on the USGS — the Federal source for science about the Earth, its natural and living resources, natural hazards, and the environment:

World Wide Web: http://www.usgs.gov

Telephone: 1-888-ASK-USGS

Any use of trade, product, or firm names is for descriptive purposes only and does not imply endorsement by the U.S. Government.

Although this report is in the public domain, permission must be secured from the individual copyright owners to reproduce any copyrighted materials contained within this report.

Suggested citation:

Allen, Y.C., Constant, G.C., and Couvillion, B.R., 2008, Preliminary classification of water areas within the Atchafalaya Basin Floodway System by using Landsat imagery: U.S. Geological Survey Open-File Report 2008-1320, 14 p. 


\section{Contents}

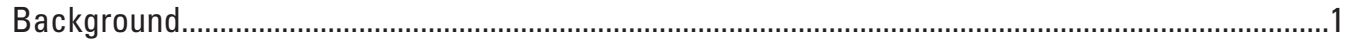

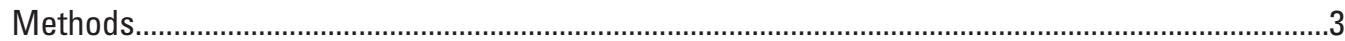

Selection and Preprocessing of Landsat Imagery ....................................................................3

Land-Water Classification in the Atchafalya Basin Floodway System......................................3

Turbid Water Classification .....................................................................................................

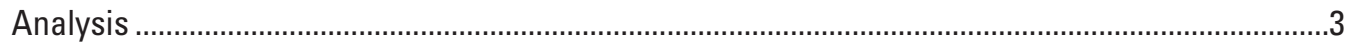

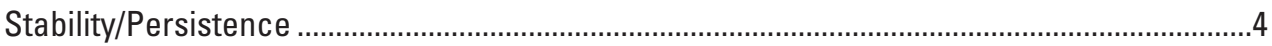

Potential Limitations ............................................................................................................

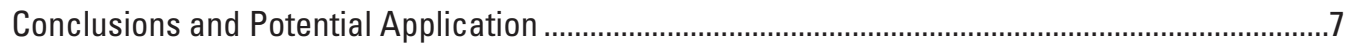

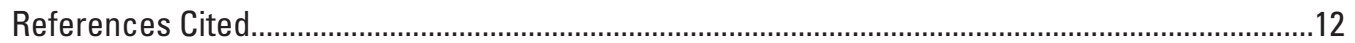

\section{Figures}

1. Map showing overview of Atchafalaya Basin Floodway System .............................................2

2. Graph showing example of the method used to choose a threshold value for land-water discrimination in the wetness band of tasseled cap transformed data

3. Illustration showing imagery (bands 4, 3, and 2); river levels at Butte La Rose, La.; land-water classification; and turbid-water classification from 1985 to 2006 .

4. Graph showing relationship between the percentage of total inundated area in the entire Atchafalaya Basin Floodway System (ABFS) and the reported river levels at the gage in Butte La Rose (BLR), La...

5. Graphs showing relationships between river levels at the Butte La Rose (BLR), La., gage and percentage of area inundated for the entire Atchafalaya Basin Floodway System (ABFS) and for each water management unit (WMU)

6. Map showing frequency of water classification among the nine Landsat images .9

7. Graphs showing stability of water classification for each water management unit (WMU) and the Atchafalaya Basin Floodway System (ABFS).....

8. Map showing frequency of turbid water classification among the nine Landsat images

\section{Tables}

1. Percentages of inundation by water for the whole Atchafalaya Basin Floodway System and each water management unit, as derived from Landsat images on nine dates.. 


\section{Conversion Factors}

Inch/Pound to SI

\begin{tabular}{|c|c|c|}
\hline Multiply & By & To obtain \\
\hline \multicolumn{3}{|c|}{ Length } \\
\hline foot $(\mathrm{ft})$ & 0.3048 & meter $(\mathrm{m})$ \\
\hline \multicolumn{3}{|l|}{ SI to Inch/Pound } \\
\hline Multiply & By & To obtain \\
\hline \multicolumn{3}{|c|}{ Length } \\
\hline meter $(\mathrm{m})$ & 3.281 & foot $(\mathrm{ft})$ \\
\hline kilometer (km) & 0.6214 & mile (mi) \\
\hline meter $(\mathrm{m})$ & 1.094 & yard (yd) \\
\hline \multicolumn{3}{|c|}{ Area } \\
\hline square kilometer $\left(\mathrm{km}^{2}\right)$ & 247.1 & acre \\
\hline square kilometer $\left(\mathrm{km}^{2}\right)$ & 0.3861 & square mile $\left(\mathrm{mi}^{2}\right)$ \\
\hline
\end{tabular}




\title{
Preliminary Classification of Water Areas Within the Atchafalaya Basin Floodway System by Using Landsat Imagery
}

\author{
By Yvonne C. Allen, 'Glenn C. Constant, ${ }^{2}$ and Brady R. Couvillion ${ }^{3}$
}

\section{Background}

The southern portion of the Atchafalaya Basin Floodway System (ABFS) is a large area $\left(2,571 \mathrm{~km}^{2}\right)$ in south central Louisiana bounded on the east and west sides by a levee system (fig. 1). The ABFS performs two major and complementary services that define its unique character. Upstream floodway structures allow roughly one-third of the combined waters of the Mississippi and Red Rivers to regularly flow into the ABFS. The main stem of the Atchafalaya River is a major navigational corridor, and, in the event of a major flood in upstream waters, up to onehalf of the flood waters can be directed to the ABFS. As a consequence of frequent flooding, the ABFS is a sparsely populated area that includes some of the Nation's most significant extents of bottomland hardwoods, swamps, bayous, and backwater lakes, holding a rich abundance and diversity of terrestrial and aquatic species.

The ABFS also hosts commercial and recreational users targeting cypress forests, crawfish, and finfish resources. Public interests also extend beyond the confines of the basin to coastal restoration efforts aimed at maintaining sediment delivery to attenuate wetland loss along the coast. Proponents of reducing hypoxia in the Gulf of Mexico are interested in the potential for denitrification in the ABFS via wetland filtration. As these management objectives are prioritized and resources are allocated to specific objectives, having a means of identifying and quantifying water distribution and flow patterns through and out of the ABFS will become increasingly important.

Within the ABFS, a complex structure of lakes, rivers, canals, and spoil banks has formed by natural and engineered processes. Because of this morphological diversity within the system, the U.S. Army Corps of Engineers has identified 13 subbasins or water management units (WMUs) (USACE, 1982) within the basin (fig. 1). The distribution and quality of water within each of these WMUs are primarily driven by water level found in the main river channels flowing through the ABFS; however, because of the unique character of each WMU, fluctuating river levels can result in very different patterns of water distribution among the WMUs.

The seasonal flow of water through the ABFS is critical to maintaining its ecological integrity. Abundant research has demonstrated that the extent, duration, and composition of water distribution in the ABFS define the composition, condition, and abundance of terrestrial and aquatic species (Sabo and others, 1999; Rutherford and others, 2001; Keim and others, 2006). In the spring, high river levels allow delivery of well-oxygenated water carrying high loads of sediment and nutrients into backwater swamp areas, improving the quality of this otherwise isolated habitat. Because of the strong interdependencies among species, habitat quality, and water flow in the ABFS, there is a need to better define the paths by which water moves at various stages of the hydrocycle. Although river level gages have collected a long historical record of water level variation, the interpretation and application of these data basinwide are limited because most of the gages are located (for practical and economic reasons) along main river channels and bayous. Very little synoptic information has been available regarding the distribution and character of water at more remote locations in the basin.

As a first step toward describing the distribution of land and water on a basin-wide scale, we chose to use Landsat 5 and Landsat 7 imagery to determine the extent of water distribution from 1985 to 2006 and at a variety of river stages. The Landsat sensors have acquired images of the Earth nearly continuously since 1984, with a 16-day repeat cycle. There are other, more recently deployed sensors that provide better spatial resolution compared to those of Landsat 5 and Landsat 7, but these sensors do not provide the extensive temporal record of Landsat. Under ideal conditions, satellite imagery can give a nearly instantaneous whole-basin snapshot of water distribution.

\footnotetext{
${ }^{1}$ U.S. Geological Survey

${ }^{2}$ U.S. Fish and Wildlife Service

${ }^{3}$ IAP World Services, Inc.
} 


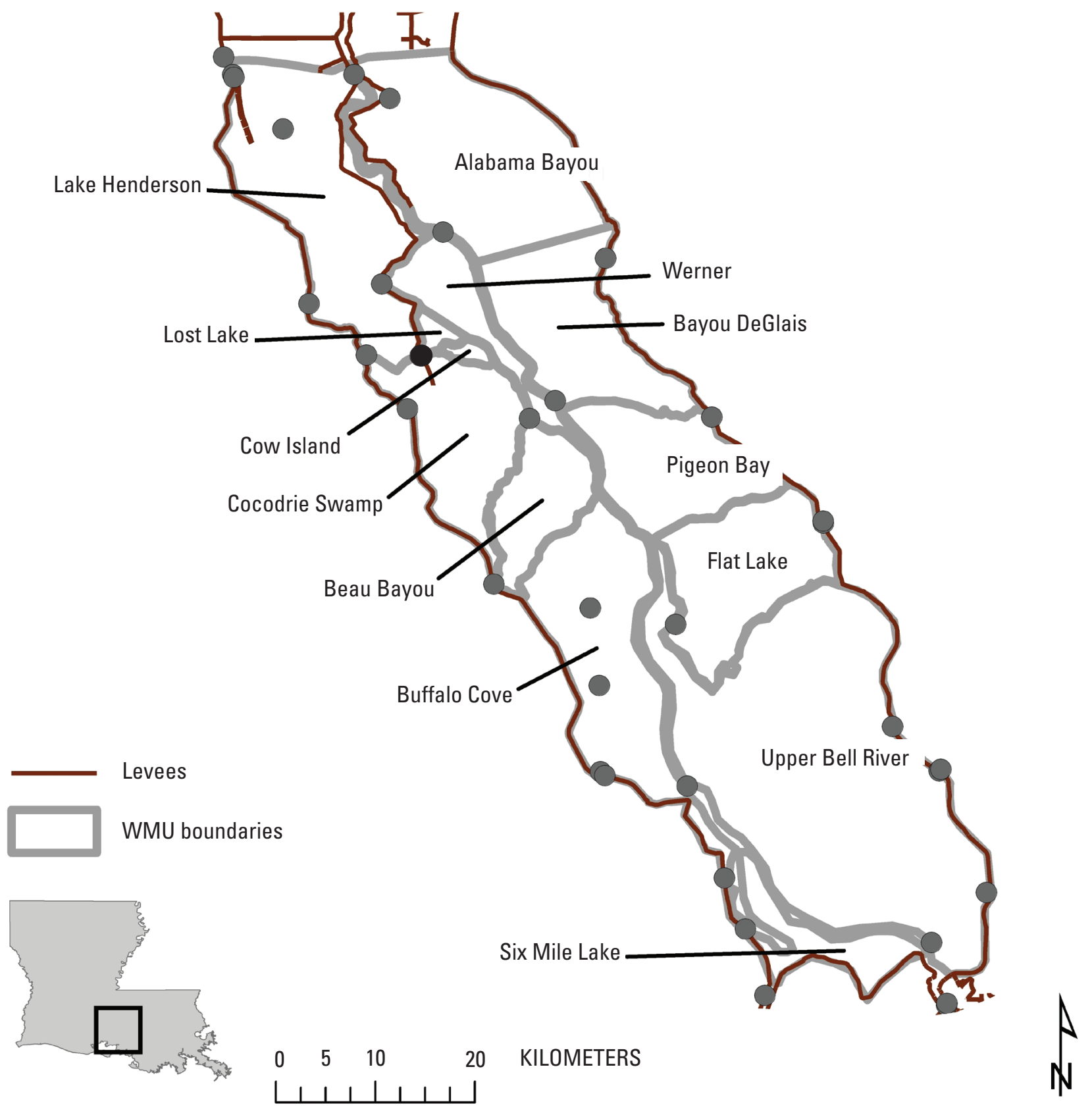

Figure 1. Overview of Atchafalaya Basin Floodway System. Water management units (WMUs), as defined by the U. S. Army Corps of Engineers (1982), are outlined in gray and labeled. Levee locations are outlined in brown. Locations of U. S. Army Corps of Engineers' gage stations are indicated by gray circles. The Butte La Rose gage station is indicated by a black circle. 
Most water management plans for the ABFS strive to improve water quality by increasing water flow and circulation from the main stem of the Atchafalaya River into isolated areas. The visual signature of river water is high turbidity. We therefore also used the Landsat imagery to describe the distribution of turbid water in the ABFS. The ability to track water flow patterns by tracking turbid waters will enhance the characterization of water movement and aid in planning as well as in tracking postconstruction impacts.

\section{Methods}

\section{Selection and Preprocessing of Landsat Imagery}

Landsat scenes that covered the entire ABFS study area (row 23, path 39) were selected from imagery, spanning from 1985 to 2006, that was previously obtained from the USGS Center for Earth Resources and Observation Science by the USGS National Wetlands Research Center's Coastal Restoration Field Station. From this archived imagery, only cloud-free images acquired during the months of January through March were selected to minimize the obscuring effects of canopy and floating vegetation. Nine images were found that satisfied these criteria. All original images were radiometrically corrected and resampled to $30-\mathrm{m}$ resolution. Images were then shifted to ensure that pixel alignment was consistent for all nine datasets. Images were then subset to the boundary of the ABFS. Each image was classified according to (1) land-water distribution and (2) turbid water distribution.

\section{Land-Water Classification in the Atchafalaya Basin Floodway System}

In this diverse swamp environment, turbid water, clear water, and floating vegetation over water may all be commonly observed in the same scene; therefore, a classification scheme focused on identifying areas based on wetness characteristics seemed most appropriate. The land-water classification approach taken in this study used a tasseled cap (TCAP) transformation to reduce the original Landsat data from six spectral bands to three transformed layers or "bands" of brightness, greenness, and wetness. A more detailed description of the TCAP transformation, its development, characteristics, and applications can be found in Kauth and Thomas (1976), Crist and Cicone (1984), Crist (1985), and Crist and Kauth (1986). For each image, threshold values to discriminate between land and water were chosen based on a strong inflection point in the histogram of the wetness band (see fig. 2). For images collected during high water (table 1), the wetness band histogram provided a clear break point that also coincided with the land-water interface interpreted from the original imagery. During lower water periods, this threshold was not as apparent from the histogram.
In these cases, threshold values were chosen solely based on manual interpretation of the original imagery. Classification results from the nine available images are shown in figure 3. Percentages of inundation results for the whole basin and for each WMU are shown in table 1.

As a check of the land-water classification effectiveness, lidar (light detection and ranging) elevation data in the Buffalo Cove WMU (fig. 1) were compared to gage data collected on the same date as the Landsat imagery. The Buffalo Cove WMU is a small, relatively homogeneous WMU with a centrally located gage that has recorded water levels for most of the dates where Landsat imagery was acquired. Each land-water classification was compared to expected water inundation extents based on lidar elevations equal to the water level observed on the date of each image. Classification results during high water periods agreed very well with the elevation data. The only differences between the Landsat classified imagery and expected results based on elevation and river gage data appeared to be caused by ponding in areas that may have flooded during previous high-water events and that had not yet drained. For images collected during low water, comparison with the lidar elevations was not useful because barriers to flow within the WMU become more apparent. The water level measured at the gage may be isolated and therefore independent from conditions in the rest of the WMU. For the Buffalo Cove WMU, an additional problem was caused by the fact that the lidar data were not collected during extremely low water conditions, and consequently, reported elevations may be of water surface rather than land.

\section{Turbid Water Classification}

Unlike the broader classification of land and water, this analysis focused on identifying only one class of water. Water typically has lower reflectance in the near-infrared bands. Turbid water has higher reflectance in the red wavelengths compared to clear water. By using these two characteristics, thresholds were identified within bands 3 and 5 that accurately isolated areas of turbid water within each image. The threshold values for turbid versus nonturbid water were not as well defined as for the land-water classification. Results from this exercise should therefore be seen as more subjective. The results generally identify areas that may have received welloxygenated water and higher sediment distribution under river conditions occurring at that time (fig. 3 ).

\section{Analysis}

Based on land-water classification of the available imagery, the percentage of inundation in the entire ABFS was significantly $(\mathrm{p}<0.01)$ related to river levels at a single, key gage station (USGS gage number 07381515) at Butte La Rose (BLR), La. (fig. 4). This relationship also held true for 9 of the 13 WMUs (fig. 5), but in the Alabama Bayou WMU, the 


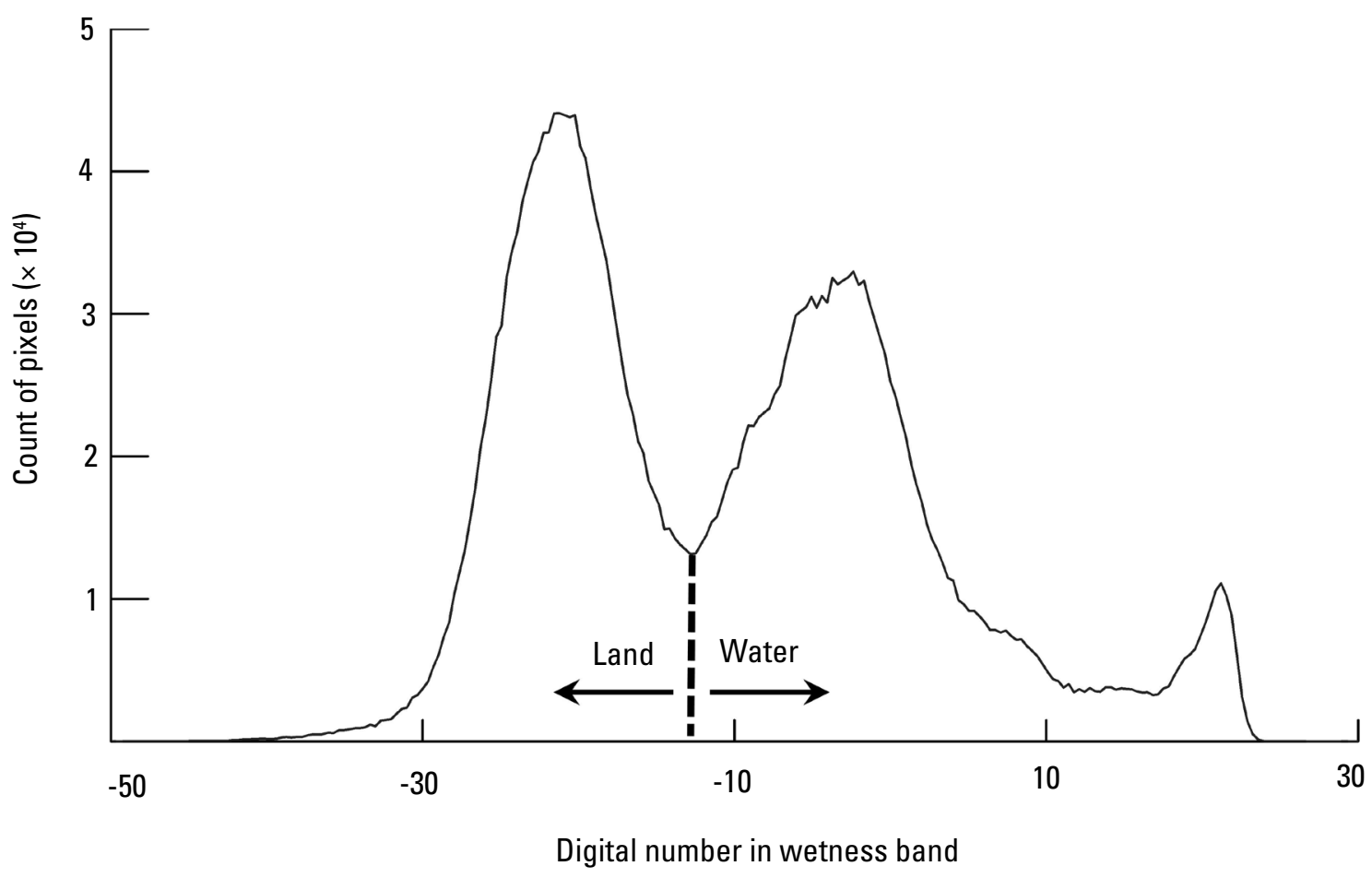

Figure 2. Example of the method used to choose a threshold value for land-water discrimination in the wetness band of tasseled cap transformed data. For each image, the threshold value chosen to discriminate between land and water was equal to the digital number associated with a strong inflection point in the histogram of the wetness band. In the above example the threshold value chosen was -12. Depicted data are for February 5, 2006.

relationship was only mildly significant $(\mathrm{p}=0.023)$. The extent of inundation within the Cow Island, Lost Lake, and Werner WMUs was not significantly related to river levels reported at BLR.

The slope of the relationship between percentage of inundation and river level at BLR did not differ compared to the whole-basin relationship for 10 of the WMUs (analysis of covariance test for homogeneity of slopes). For the Werner WMU, the slope was significantly different $(\mathrm{p}=0.021)$ from the whole-basin relationship, but the significance was modest. For the Cow Island and Lost Lake WMUs, the slope of the relationship differed significantly compared to the same relationship for the whole basin ( $\mathrm{p}<0.01)$.

It should be noted, however, that these relationships are based on a relatively limited number of images. We expect that a simple linear relationship with one key gage station for the whole basin may not be appropriate under all water levels. Under low water conditions, for example, the water level dynamics within a WMU may become significantly uncoupled from water levels in the main stem of the river because of emerging barriers such as levees and spoilbanks. More images should be analyzed to confirm the robustness of these relationships.

\section{Stability/Persistence}

For each WMU, the land-water classifications were used to identify areas that were consistently classified as land, consistently classified as water, or variably classified as land or water depending primarily upon river conditions. Such an analysis can have important implications for various tree species having specific tolerances of flooding for successful growth and reproduction. The classification for each pixel was compared across all nine images. The frequency of classification as water is depicted in figure 6.

This analysis was further used to identify the percentage and locations of areas that were "stable"-consistently classified as land or consistently classified as water-within each WMU. Results show that the WMUs display a range of stability characteristics. The Cow Island WMU shows the highest degree of classification stability (fig. 7). Most locations within this WMU were consistently classified as land or water, regardless of river level. In contrast, Beau Bayou WMU shows a high degree of instability based on the classified imagery. Flooding and drying out occurred regularly over a large portion of this WMU. Much of the Alabama Bayou, Werner, and Lost Lake WMUs were consistently 


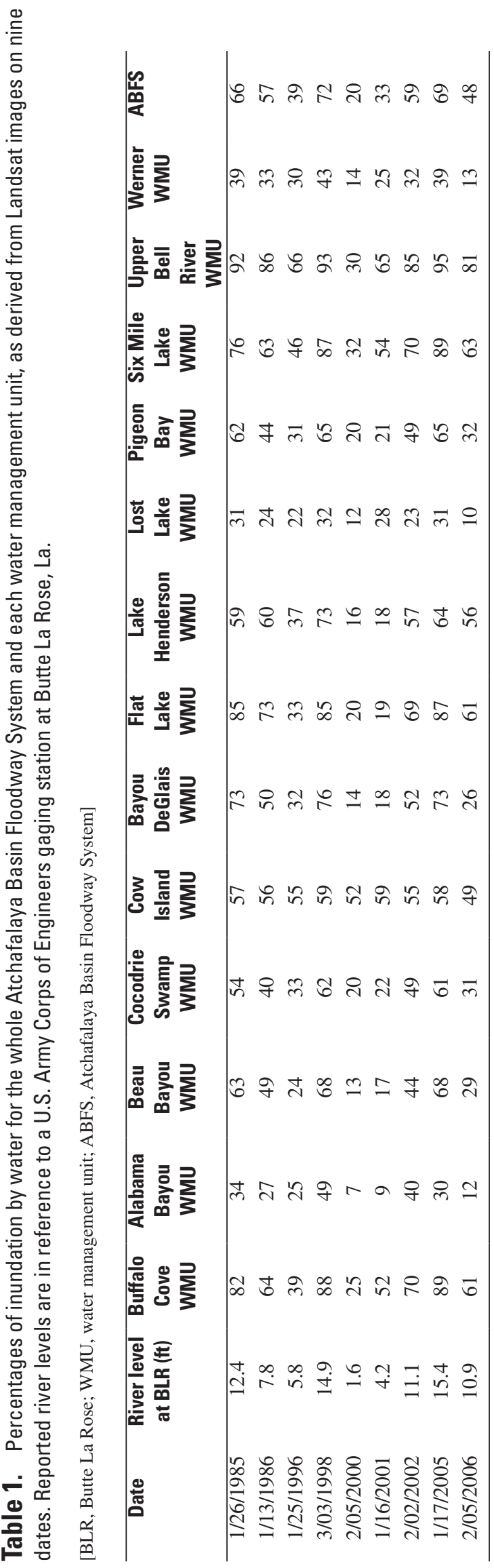



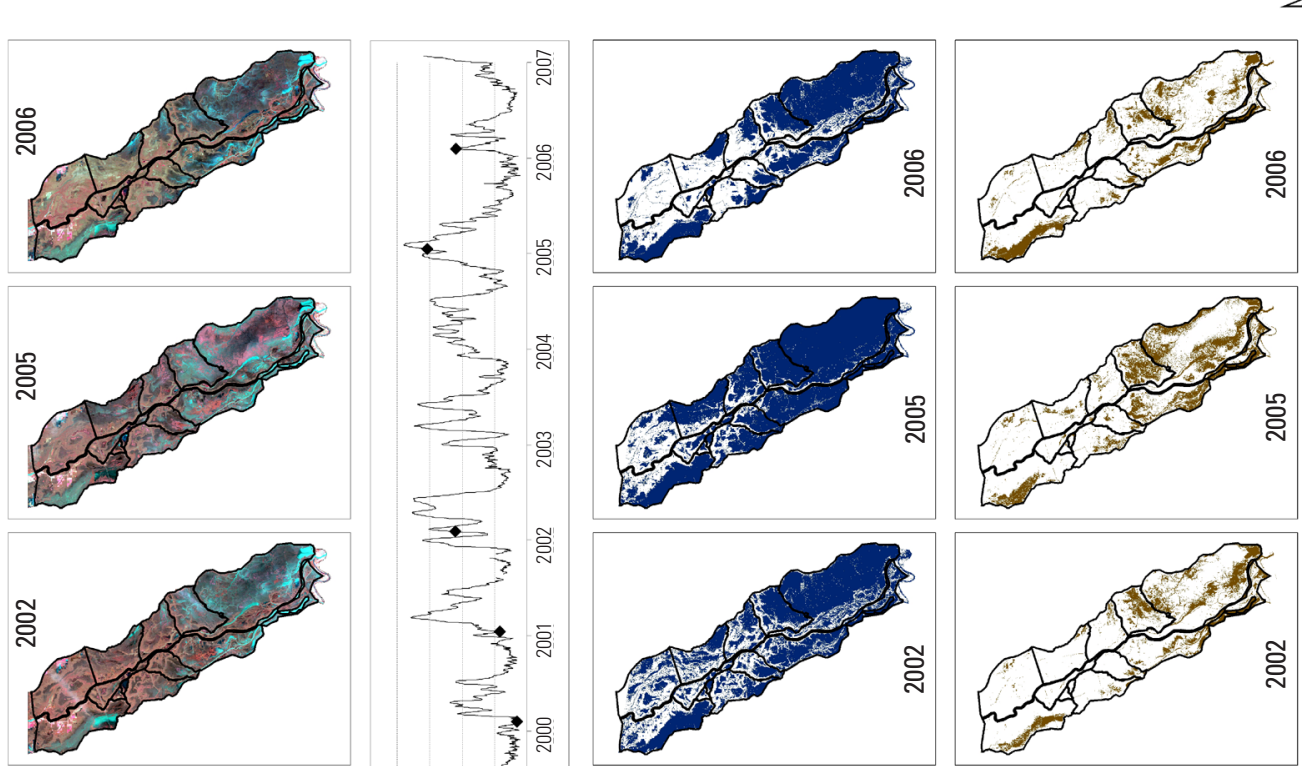

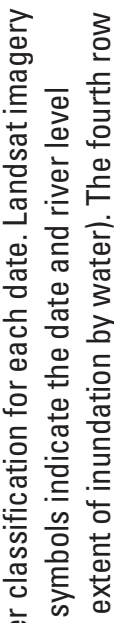

के के

3 要

은 흥 흉



둔
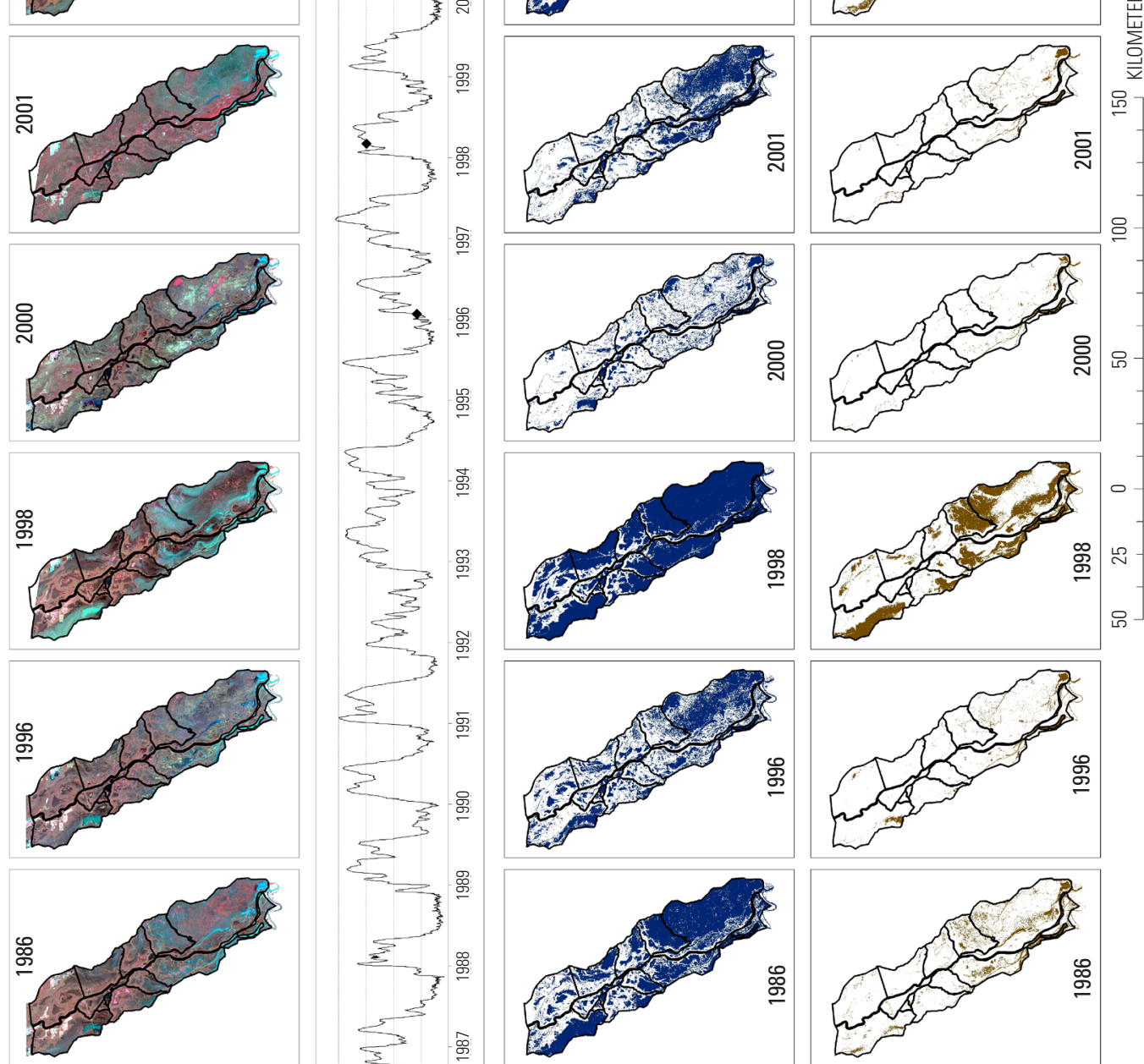

产

竞

捗 $\cong \frac{9}{0}$

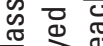

उ

要

要

뜨융

荬

心范

实高苋

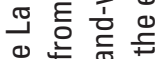

春

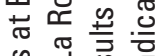

잉

志志志

㐫茫范

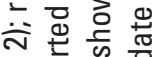

든 응 긍 등

ल क क 흥

o

힌

㐫

궁

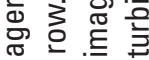

皇 응 등

敢

등

西.

d d

m $\frac{\pi}{2}$

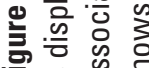
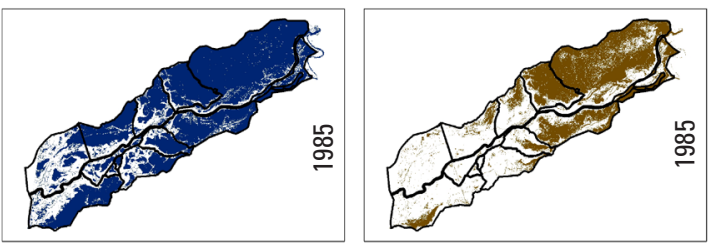

1ำ 


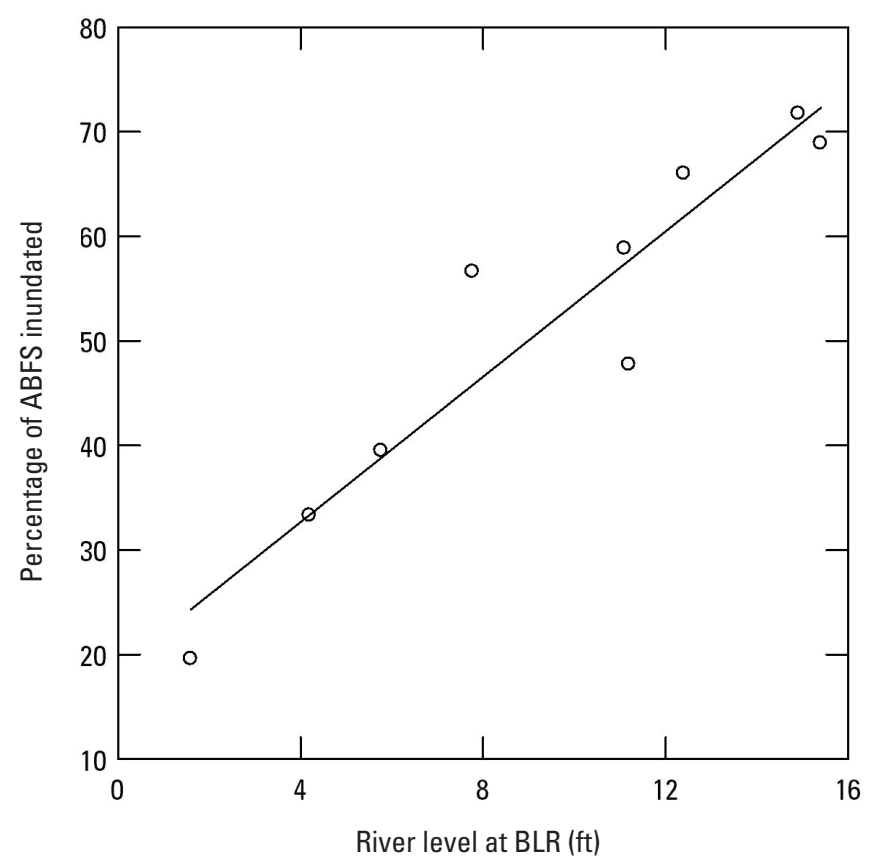

Figure 4. Relationship between the percentage of total inundated area in the entire Atchafalaya Basin Floodway System (ABFS) and the reported river levels at the gage in Butte La Rose (BLR), La. $\left(r^{2}=0.88 ; p<0.01\right)$.

classified as land, while most of the Upper Bell River and Six Mile Lake WMUs were frequently classified as water.

A similar analysis was conducted by using the turbid water classifications. For each pixel, the frequency of classification as turbid water was evaluated. The resulting map (fig. 8) gives an indication of areas that consistently receive distributions of sediment-laden water. This analysis can be compared to more detailed in situ studies that seek to evaluate differential accretion rates within the basin.

\section{Potential Limitations}

There are several factors that will limit the accuracy of these results for specific applications. First, the pixel size of the Landsat imagery is $30 \mathrm{~m}$, but many of the channels and bayous carrying water and sediment through the ABFS are narrower than $30 \mathrm{~m}$. In a diverse environment, such as a narrow channel with spoil banks on either side, the Landsat reflectance for that pixel will incorporate spectral information from the entire $30-$ by $30-\mathrm{m}$ area. The analysis presented here is best viewed at the whole-basin or individual WMU scale. Examination of classification on the single-pixel scale in highly diverse environments is therefore inappropriate.

Secondly, at this time, our analysis is purely retrospective, with only limited ground truthing possible based on available gage and elevation data. In the future, we plan to schedule field collections to coincide with satellite overflights on clear days in order to provide more rigorous ground truthing of the data.
Third, our analyses were limited to imagery on hand. Given the dynamic seasonal and long-term character of the basin, it would be prudent to carry out these same analyses by using a larger selection of imagery. The evaluation of turbid water distribution was particularly limited since water levels were low in three of the nine images (1996, 2000, and 2001), and turbid water under these conditions was largely confined to the main river channels and larger bayous. Analysis of more high-water images would provide a more reliable estimate of sediment distribution. Conversely, analysis of more low-water imagery should provide a more reliable map of persistently wet areas.

Finally, the wetness band algorithm for land-water classification does not perform perfectly under all seasonal conditions. For the ABFS study area, the default coefficients for TCAP assign high wetness values to regions with healthy vegetation. This system works well when classifying imagery captured during winter months when floating aquatic vegetation is the only healthy vegetation present. In such images, areas having abundant aquatic vegetation are correctly classified as water. The algorithm does not, however, provide an accurate discrimination of water and land in nonwinter months. In nonwinter months, many upland areas receive higher wetness values because of the presence of healthy and more abundant vegetation, which leads to frequent misclassification of land as water. Wetness band thresholding therefore appears effective in discriminating land and water when aquatic vegetation is the only vigorous vegetation in the Landsat scene. Future studies will compare alternative techniques for land-water discrimination.

\section{Conclusions and Potential Application}

Classification of wet areas by using Landsat imagery provides a basin-wide level of detail not previously available. Gage data can provide some corroboration of the results presented here, but gage data are strongly limited in a number of ways: (1) they are sparsely available relative to the size and complexity of the basin, (2) gages are not typically located in remote swamp areas that are readily observable from satellite imagery, and (3) they may not be relevant even for local applications if there are local elevation differences causing impediments to water flow.

Landsat data classified as land and water, when used in conjunction with gage data, can provide much greater information pertinent to the understanding of water and sediment distribution throughout the basin. More imagery and more land-water and turbid water analyses will build a library of inundation extents and turbid water distribution. This map library can then be used as a reference to refine predictions of inundation extent under various flooding scenarios. A historical record of turbid water distribution could also allow managers to identify open water areas that have consistently received high levels of sediment. Such areas may be at risk for conversion to land due to sediment accretion. 

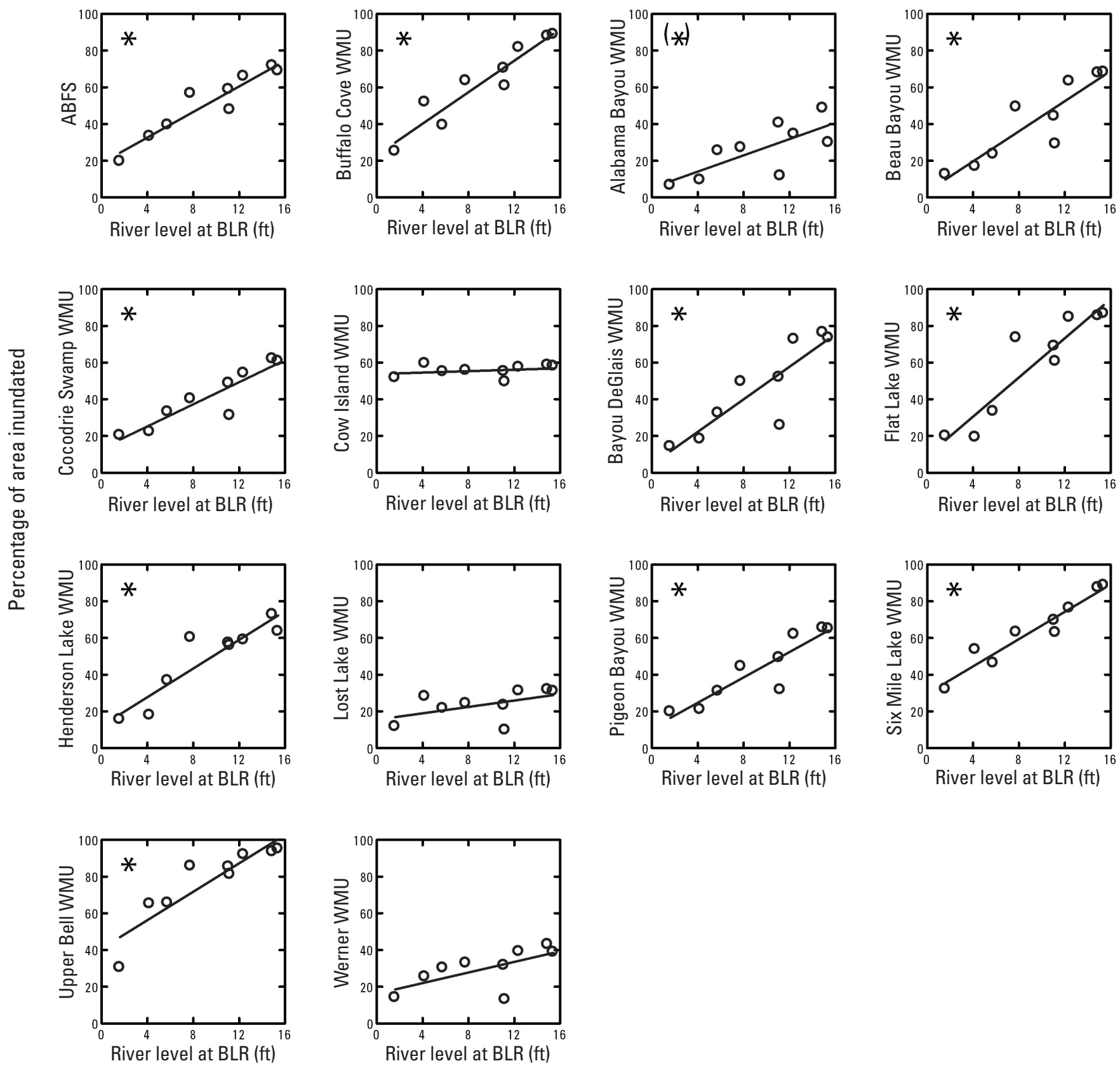

Figure 5. Relationships between river levels at the Butte La Rose (BLR), La., gage and percentage of area inundated for the entire Atchafalaya Basin Floodway System (ABFS) and for each water management unit (WMU). Significant relationships ( $p<0.01)$ are indicated with an *, but in the Alabama Bayou WMU, the relationship was only mildly significant $(0.01<p<0.05)$. 
Frequency of water classification
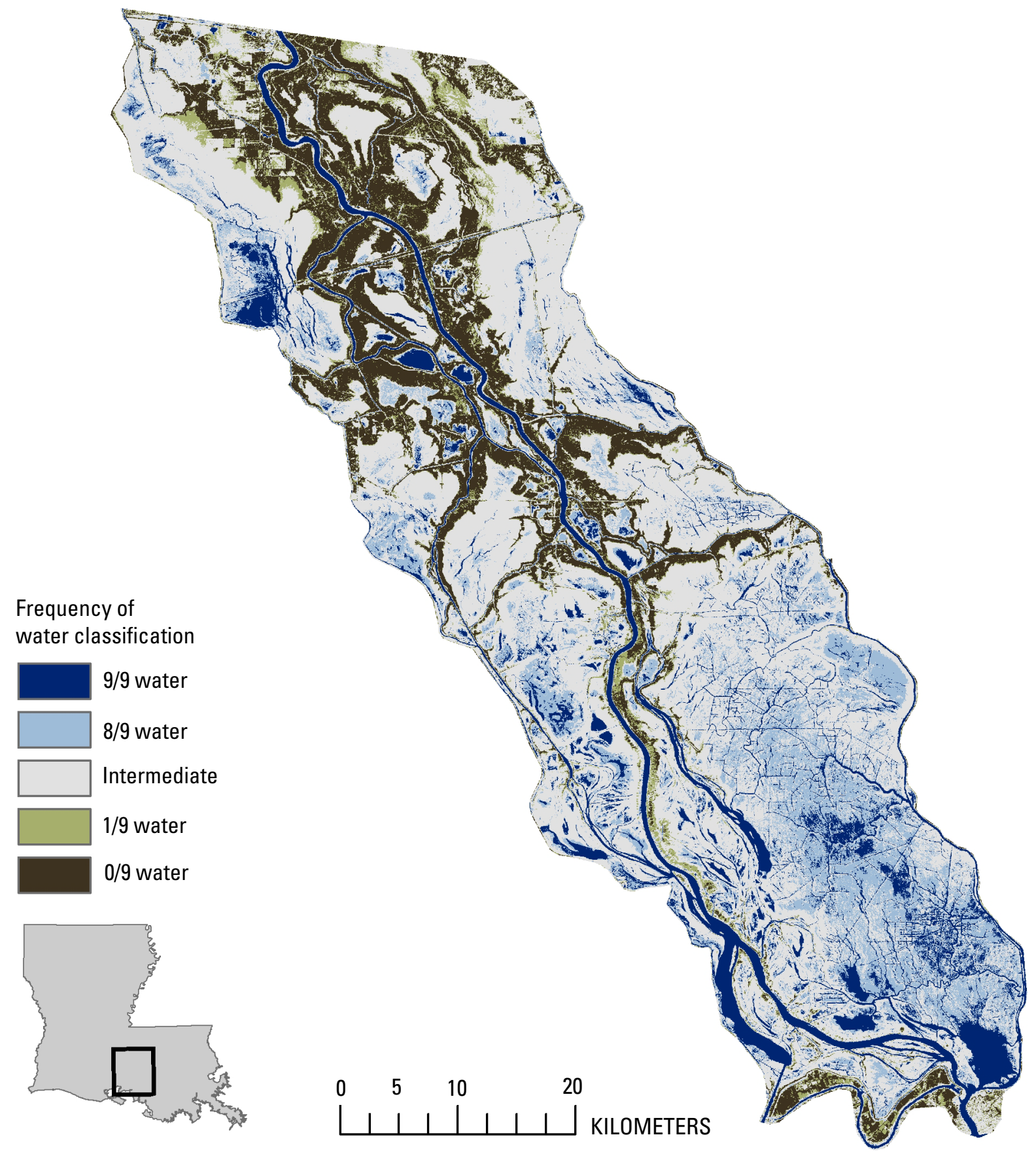

Figure 6. Frequency of water classification among the nine Landsat images. 


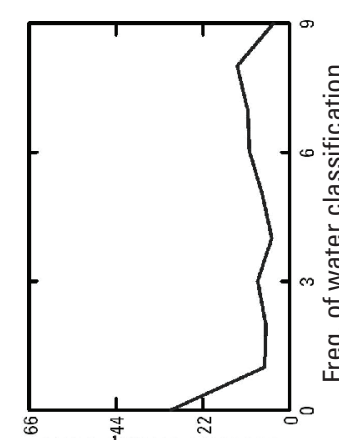

กWM duems ә!بpoэoj
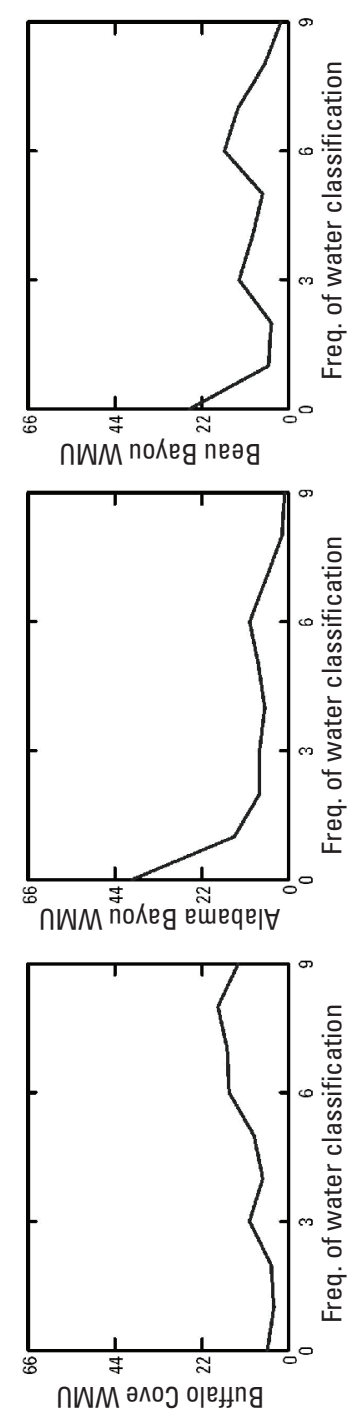

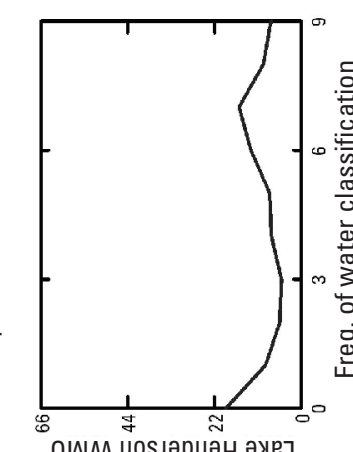

กWM Uоsıәриән әуеך

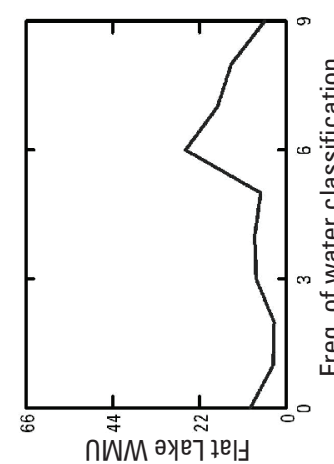

nWM әуеүнеу
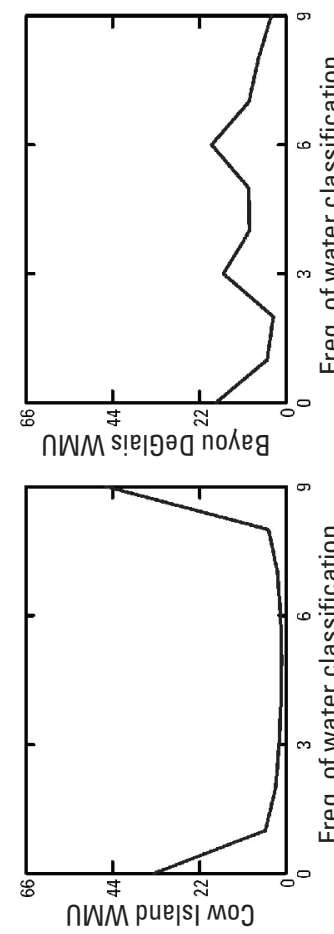

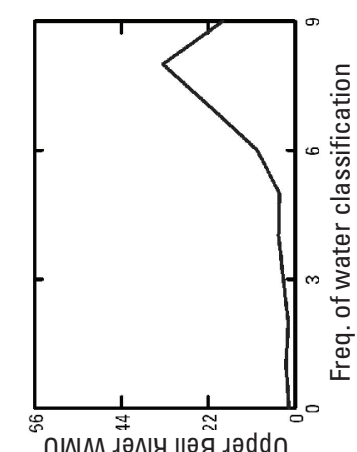

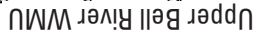
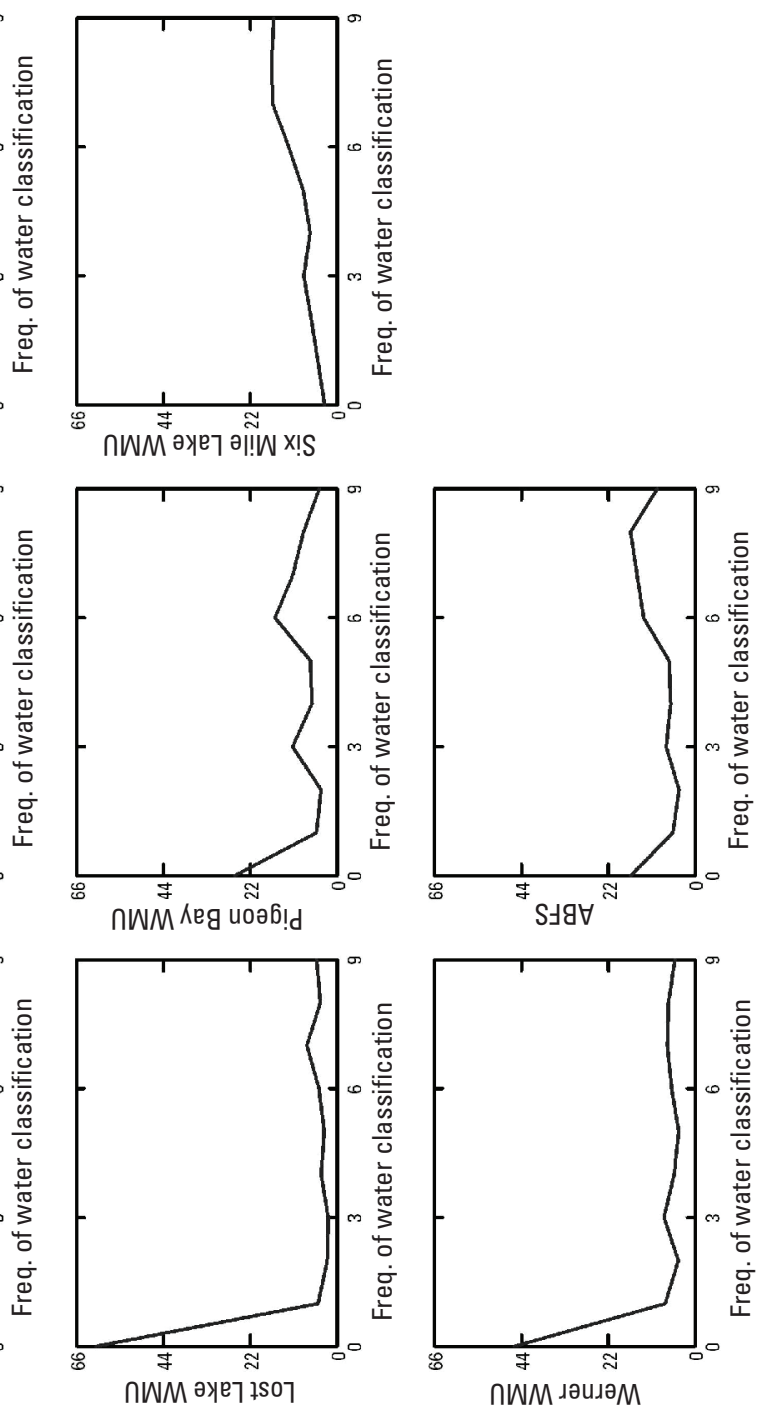

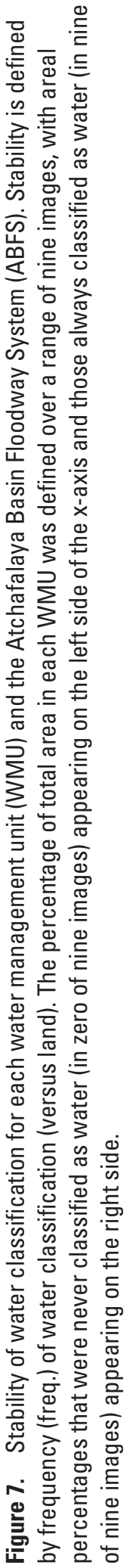




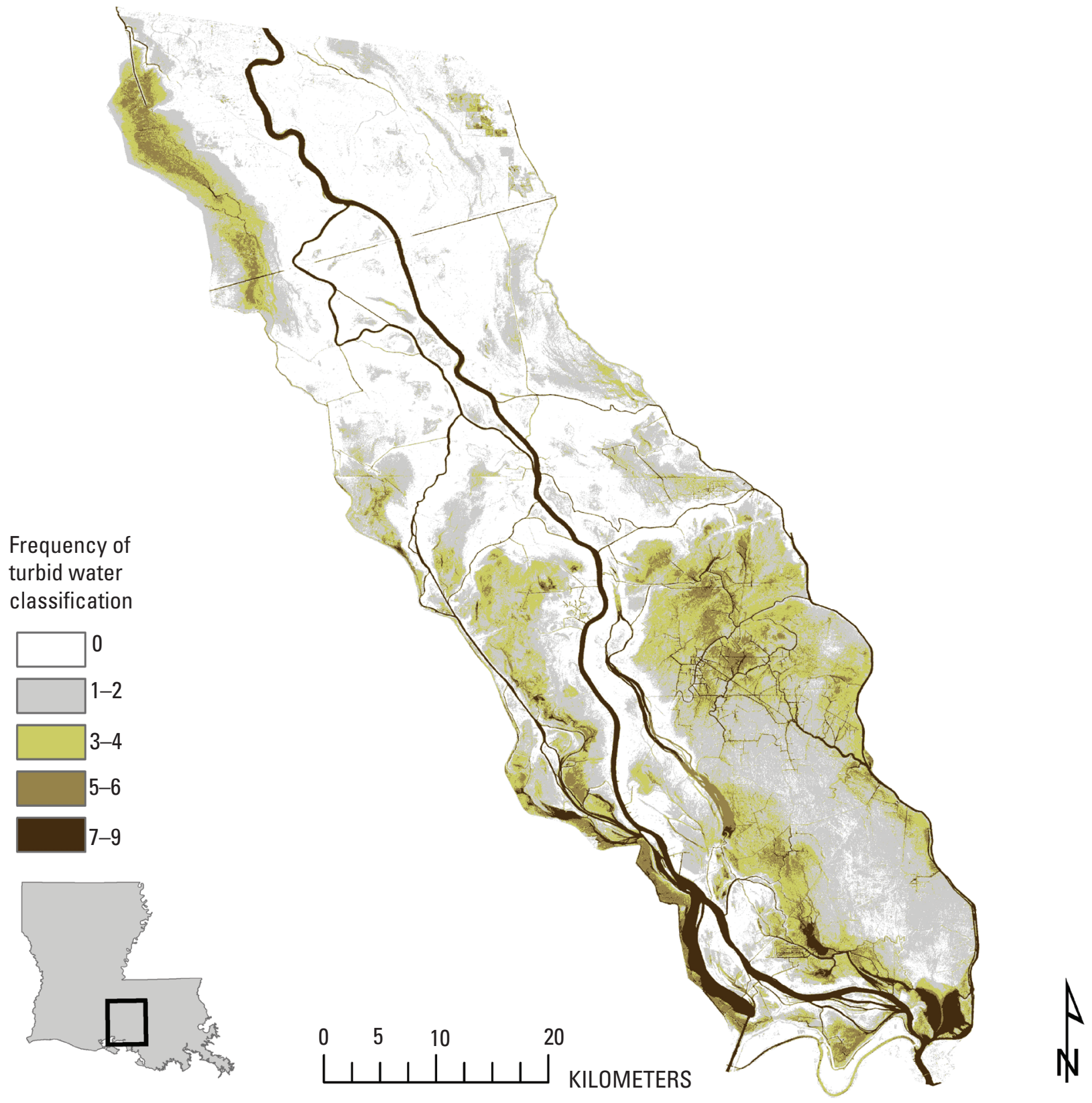

Figure 8. Frequency of turbid water classification among the nine Landsat images. 


\section{References Cited}

Crist, E.P., 1985, A TM tasseled cap equivalent transformation for reflectance factor data: Remote Sensing of Environment, v.17, p.301-306.

Crist, E.P., and Cicone, R.C., 1984, A physically-based transformation of Thematic Mapper data - the TM tasseled cap: IEEE Transactions on Geosciences and Remote Sensing, v. GE-22, p. 256-263.

Crist, E.P., and Kauth, R.J., 1986, The tasseled cap demystified: Photogrammetric Engineering \& Remote Sensing, v. 52, p. 81-86.

Kauth, R.J., and Thomas, G.S., 1976, The tasseled cap-a graphic description of the spectral-temporal development of agricultural crops as seen in Landsat, in Proceedings on the Symposium on Machine Processing of Remotely Sensed Data, West Lafayette, Ind., June 29-July 1, 1976: LARS, Purdue University, West Lafayette, Ind., p. 41-51.

Keim, R.F., Chambers, J.L., Hughes, M.S., Nyman, J.A., Miller, C.A., and Amos, J.B., 2006, Ecological consequences of changing hydrological conditions in wetland forests of coastal Louisiana, in Xu, Y.J., and Singh, V.P., eds., Coastal environment and water quality: Water Resources Publications, Highlands Ranch, Colo., p. 383-396.

Rutherford, D.A., Gelwicks, K.R., and Kelso, W.E., 2001, Physicochemical effects of the flood pulse on fishes in the Atchafalaya River Basin, Louisiana: Transactions of the American Fisheries Society, v. 130, p. 276-288.

Sabo, M.J., Bryan, C.F., Kelso, W.E., and Rutherford, D.A., 1999, Hydrology and aquatic habitat characteristics of a riverine swamp-I. Influence of flow on water temperature and chemistry: Regulated Rivers-Research and Management, v. 15 , p. 505-523.

U. S. Army Corps of Engineers (USACE), 1982, Atchafalaya Basin Floodway System feasibility study-Main report and final environmental impact statement, vol. I: New Orleans, La., U.S. Army Corps of Engineers, 358 p. 

Publishing support provided by the Lafayette Publishing Service Center 
